\title{
BEDROCK CHARACTERISTICS OF SELECTED COVERED KARST SITES IN THE MALOPOLSKA UPLAND
}

\author{
DOROTA BRZOZOWICZ
}

\begin{abstract}
The article describes the nature of the bedrock in areas in the Małopolska Upland where landforms associated with covered karst processes occur. It seeks to find a relationship between geological structure and the potential for covered karst processes to develop. To this end, it includes a review of the literature on the geological structure of three areas in the mesoregions of Wzgórza Opoczyńskie, Niecka Włoszczowska and Niecka Solecka. Two of the three sites are located in an area of limestone karst, and the third (located in Niecka Solecka) is an area of gypsum karst. All three sites were filled with sediment in the Holocene, but the forms being studied probably formed much earlier. The author also attempts to reconstruct the relief of the Mesozoic surface as digital terrain models. For this purpose, data was taken from geological drillings contained in geological maps of Poland and developed using GIS software. According to digital terrain models in the form of 3D views all three investigated sites are located in a depressions in the Mesozoic surface (on the slopes or bottom of the basin). That location and low thickness of impervious deposits has caused that migration of underground water, which can affect karstified rocks with increased intensity.
\end{abstract}

Key words: karst landform, Mesozoic surface, digital terrain model, undrained depressions

\section{Introduction}

For several years, research has been underway into biogenic infillings deposited in closed depressions whose genesis is associated with covered karst processes in the Małopolska Upland (Kobojek 2004; Kobojek, Nalej 2008; Brzozowicz, Forysiak 2016; Brzozowicz 2016a, b, 2018). The karst origin of the depressions in this area has previously been identified by Różycki (1946) and Nowak (1971). The basic mechanism shaping this type of landform is the formation of gaps in karst rocks, and their subsequent filling with an overlying layer of sediments not subject to karst processes. This causes undrained depressions to form in the land surface. The course of this process depends on the geological structure of the substrate, and particularly on the petrography (types of rocks forming the karstic bedrock), tectonics, and the thickness of the unconsolidated sediments constituting surface layers. Research is being carried out in three areas, in each of which, one depression filled with biogenic deposits was selected for detailed palaeoecological research. Their varied locations and differences in the geological structure of the bedrock may indicate specific conditions conducive to the formation and development of covered karst landforms. The processes of filling these forms with sediments began in the Holocene, but, according to Głazek (1989), karst processes in this region were active much earlier.

This study presents an analysis of the geological structures of selected sites. The first, the Daleszewice site, is located in the north of Wzgórza Opoczyńskie (the Opoczno Hills) (Kondracki 1998) at the northern end of the Małopolska Upland (Fig. 1). The site covers a 40-m-diameter drainless basin completely filled with sediments. These are biogenic sediments to a depth of $320 \mathrm{~cm}$, and particularly peat with medium and high degrees of decomposition. At the southern border of the region is the Gaik-Winiary site, in Niecka Solecka (the Solec Trough). It is a depression with dimensions of $85 \times 60 \mathrm{~m}$ and a depth of at least $310 \mathrm{~cm}$. It is completely filled with biogenic sediments in the form of lake silt, gyttja and peat. Meanwhile, the Łykawe Doły site is at the border of the Małopolska Upland and the Śląsk-Kraków Upland in the western part of Niecka Włoszczowska (the Włoszczowa Trough). It is a $40 \times 15 \mathrm{~m}$ depression only partially filled with sediments. The sediment ceiling is approx. $1.5 \mathrm{~m}$ from the ground surface, and $234 \mathrm{~cm}$ of peat sediments were drilled below it.

\footnotetext{
${ }^{1}$ Uniwersytet Łódzki, Wydział Nauk Geograficznych, Katedra Geologii i Geomorfologii, ul. Narutowicza 88, 90-139 Łódź; e-mail: dorota.brzozowicz@edu.uni.lodz.pl, ORCID: 0000-0002-8553-5121
} 


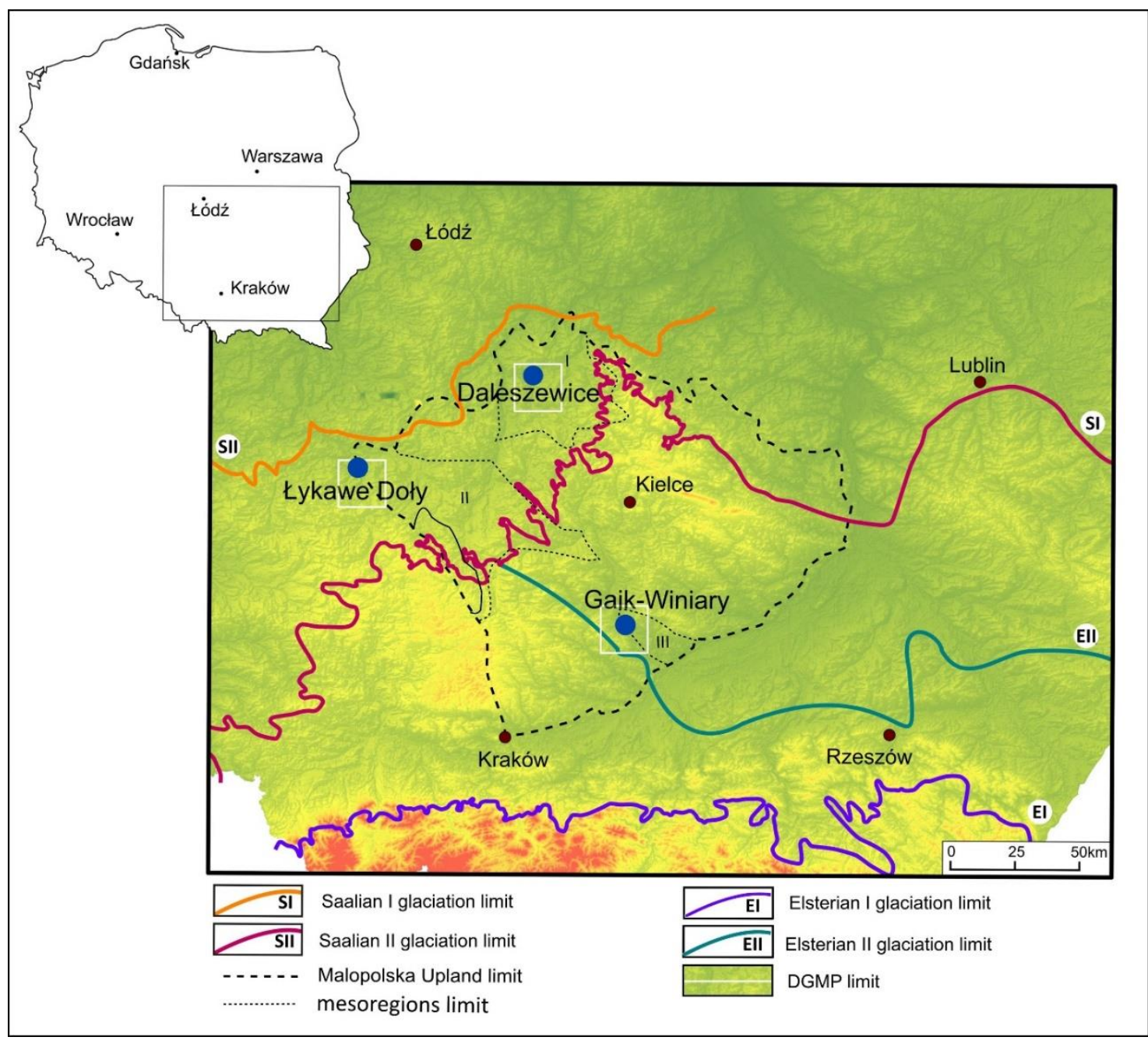

Fig. 1. Location of sites in the Małopolska Upland (Kondracki 1998) with glaciation limits: Elsterian I, Elsterian II, Saalian I (Marks et al. 2016) and the Saalian II (Rdzany 2009)

mesoregions: I - Wzgórza Opoczyńskie (Opoczno Hills), II - Niecka Włoszczowska (Włoszczowa Trough), III - Niecka Solecka (Solec Trough) (Kondracki 1998)

More attention was focused on the relief of the top of the Mesozoic rock, where the karst processes are developing. To better illustrate the importance of the shape of the top of the Mesozoic rocks in the processes, an attempt was made to reconstruct the sub-Cenozoic bedrock as threedimensional maps.

\section{Methods}

To analyse the geological structure in detail, the literature was reviewed, and geological maps of the research areas were analysed - principally the 1:50,000 Detailed Geological Map of Poland (DGMP). The map explanations in the DGMP contain particularly important information on geological structure, with a detailed description of in- dividual rock layers in the immediate vicinity of the analysed sites.

Using ArcGIS tools, a reconstruction of the sub-Cenozoic bedrock was attempted for the areas covered by the Żarnów (Janiec 1988), Busko Zdrój (Łyczewska 1972a) and Ostrowy (Kaziuk, Nowak 1999) sheets of the DGMP based on purposely conducted geological drillings (Daleszewice - 103 drillings, Busko Zdrój - 28 drillings, Ostrowy - 50 drillings). The reconstruction was made by selecting points indicating the depth of occurrence of sub-Cenozoic sediments, and then mapping points with coordinates corresponding to individual drillings along with the absolute surface height of the borehole and the absolute height of the upper surface of the sub-Cenozoic bedrock. The resultant point map was then interpolated and using the ArcScene overlay it was moulded into a three-di- 
mensional topographical image. The point map was also used to determine the Cenozoic layer's thickness - and changes therein - for the different areas. For each of the three DGMP sheets, maps were made of the thickness of the Cenozoic layer and the Quaternary deposit layers, which made it possible to visualise these deposits' share in the total Cenozoic deposits.

\section{Geological structure of study area}

\section{The Daleszewice site}

The site is located within the Mid-Polish Anticlinorium in the area of the Szydłowiecki Segment, which covers the Mesozoic edge of the Palaeozoic core of the Świętokrzyskie Mountains. The northern part of the area, included in the north-eastern wing of the Szydłowiecki Segment, where the Daleszewice site is located, is characterized by the slight slope of its layers and the considerable thickness of the Mesozoic rocks (Mizerski 2020). In the north-eastern part of the Szydłowiecki Segment, there are numerous Laramiian and Variscan faults which do not extend to the research area.

The site is located within an occurrence of limestone karst in the north of Wzgórza Opoczyńskie. The area of the DGMP Żarnów (Janiec 1988,1993 ) sheet containing the research site is characterised by the occurrence of postglacial sediments in the northern part, with tills on the surface, while much of the central part of this map sheet is occupied by outcrops of Early Jurassic sandstones interbedded with mudstones and claystones.

In the subsoil of the Daleszewice site, under a thin (up to $20 \mathrm{~m}$ ) but continuous layer of Quaternary sediments, there is a layer of Neogene Terra Rosa waste-mantle (Janiec 1993) laid down in lobes. However, the Quaternary deposits usually directly overlie Jurassic limestone deposits. In the vicinity of the Daleszewice site, a more than $300 \mathrm{~m}$ thick Jurassic layer was drilled. The deepest deposits are Middle Jurassic sandstones calcareous, dolomitic, marly, chloritic, organodetrital and conglomerate sandstones - plus clays and claystones, mudstones, conglomerates and siderites. These are overlain by a more than 200-mthick layer of Late Jurassic sediments in the form of: platy, marly, reef and sponge limestones; limestones with flints; ooidal limestones; and marls. The Quaternary layer consists of three layers of glacial tills separated by sand lenses and glaciolacustrine silts. The first consists of till from the period of the South Poland Glaciation, which is deposited as lobes, usually in places where the Neogene layer is discontinuous. These are overlain by glacial till of up to 1-m-thick from the Saalian I glaciation. Meanwhile, the surface layer is made of till of similar thickness from the Saalian II (Janiec 1988, 1993).

The Daleszewice site lies within the Pilica River catchment area. The nearest watercourse is Pogorzelec, flowing about $3 \mathrm{~km}$ west of the site. The first aquifer is the Quaternary level, the water table of which is at $2-5 \mathrm{~m}$. The second aquifer is the Upper Jurassic level, the upper surface of which is at a depth of 10 to $46 \mathrm{~m}$ at a short distance from the site (Janiec 1993).

\section{The Lykawe Doły site}

The site lies within the Szczecin-Miechów Synclinorium, immediately adjacent to the border with the Przedsudecka Monocline, in the northwestern part of the Miechów Segment. The northern part of the segment is characterised by an arrangement of layers without faults and a significant thickness of the Upper Jurassic layer (up to 1000 m) (Mizerski 2020).

The Łykawe Doły site also lies within an area of covered karst processes associated with the karstification of limestone deposits thinly overlain by Quaternary deposits (Kobojek 2004). The Ostrowy map sheet of the DGMP (Kaziuk, Nowak 1999) covers a fragment of frontal moraine from the Saalian I glaciation's maximum range. Characteristic of this area are its numerous outcrops of Jurassic rocks. Across the entire sheet, the Jurassic rocks lie not very deep below the surface. The greatest recorded depth of the top of Jurassic formations is $90 \mathrm{~m}$, around the village of Szarlejka. On average, the layer is about 30-40m-deep. Across most of the sheet, the uppermost Jurassic layer is formed of Oxfordian-age rocks, such as marls and marly, bedded, rocky, detritic and chalky limestones. In small depressions, $\mathrm{Ne}$ ogene deposits such as clays, silts and sands with lignite are recorded, as well as sands with limestone rocky rubble (Kaziuk, Nowak 2014). Usually, however, the Jurassic layer is directly overlain by Quaternary postglacial deposits composed of three layers of glaciofluvial sands separated by two layers of glacial tills (three in places). These deposits are associated with the action of ice sheets during the Elsterian and Saalian I glaciations. 
The bedrock around the Łykawe Doły site is of Jurassic deposits and a 40-m-thick layer of Quaternary sediments. At $327 \mathrm{~m}$ deep, drilling found Middle Jurassic formations in the form of sandy limestones, marls and marly limestones. They are overlain by a more than 280 -m-thick Late Jurassic layer of marly, bedded sponge, rocky, detritic and chalky limestones, and marls.

The Late Jurassic formations are directly overlain by Quaternary deposits. The deepest layer is of tills of the Elsterian II glaciation about 10-m-thick. Above it, there are glaciofluvial sands and gravels of up to 10-m-thick, also associated with the action of the Elsterian II ice sheet. The next layer consists of Saalian I till of up to 15-m-thick. The surface layer consists of glaciofluvial sands and gravels of the Saalian I glaciation maximum, with a thickness of about 5 m (Kaziuk, Nowak 2014).

The Łykawe Doły site is located between the Biała Oksza River (west of the site) and Kocianka (east of the site). The first groundwater level at this point is the Upper Jurassic level, the water table of which is deeper than $5 \mathrm{~m}$ below surface (Liszka et al. 2000; Mapa hydrograficzna Polski).

\section{The Gaik-Winiary site}

The site is located on the Szczecin-Miechów Synclinorium in the southern part of the Miechów Segment. The base of the segment consists of folded Palaeozoic rocks cut with faults covered with Mesozoic sediments, the profile of which is incomplete, with numerous sedimentation gaps. In the southern part of the segment, where the Gaik-Winiary site is located, the Mesozoic sediments were covered with fold structures made of Miocene marine sediments (Mizerski 2020).

Gaik-Winiary is located in Niecka Nidziańska in an area of karst gypsum rock processes (Rutkowski 1986; Urban 2015). The bedrock, according to the Busko Zdrój sheet of the DGMP (Łyczewska 1972a), is made of four main rock layers, being:

- Late Jurassic rocks, occurring as marls, limestones and rocky limestones with inserts of slates and clays;

- Late Cretaceous deposits - mainly carbonate deposits, such as rocks, marls and limestones, as well as sandstones, sands and loams. The thickness of the Late Cretaceous may exceed $400 \mathrm{~m}$;

- an unevenly preserved layer of Neogene deposits, mainly of gypsum, anhydrites, clays, marly clays, and sands. The thickness of this layer can reach up to about $40 \mathrm{~m}$;

- a thin layer of Quaternary deposits deposited in lobes and heavily eroded. This layer is thickest within the Nida valley.

The Gaik-Winiary site lies on a plateau to the east of the Nida River valley, in a location where outcrops of Neogene rocks occur. The deepestdrilled layer is of limestones, marls, and rocky limestones with Late Jurassic slate and clay inserts, all formed as a result of an extensive marine transgression. At this site, the top of the Jurassic layer can be more than $240 \mathrm{~m}$ below the surface. The Late Jurassic sediments are directly overlain by Late Cretaceous deposits in the form of siliceous marls, marls and limestones, as well as limy sandstones, silicated limestones and flints. The thickness of the Late Cretaceous can reach $200 \mathrm{~m}$ at this point. It is overlain by Neogene sediments probably starting with marly clays and sands. The uppermost layer is made of gypsums and anhydrites of up to 37-m-thick. This layer is made of smaller layers with a thickness of up to several metres (maximum $9 \mathrm{~m}$ ). The deepest layer is of large-crystalline gypsum (crystals can reach $3 \mathrm{~m}$ in length), overlain by coarse-crystalline gypsum. The next layer is slate gypsum with clay-marl or marly limestone inserts, while the surface layer is made of cryptocrystalline gypsum with clay-marl inserts exhibiting lamellar cleavage (Łyczewska 1972b).

A precise assessment of the sedimentary stratigraphy of the site's bedrock is hampered by the area being incised by numerous fractures and faults (Lyczewska 1972a, b), and by the site being no less than $2 \mathrm{~km}$ from where the deep geological drillings were made. It should be noted that, at the Gaik-Winiary site, the Neogene gypsum deposits are of primary importance for the development of karst phenomena.

The Gaik-Winiary site is located within the Nida River catchment area, to the north of its channel. The site is drained by an artificial drainage ditch. Gaik-Winiary is located within a chalk aquifer, but the Miocene water level is of greatest importance for the development of karst processes. These waters feed karst springs, and the level of their upper surface at the site of the GaikWiniary reservoir is deeper than $2 \mathrm{~m}$ below the surface (Gałka 2006). 


\section{Characteristic of the sub-Cenozoic surface}

\section{The Daleszewice site}

The thickness of Cenozoic formations within the area of the Żarnów sheet (Janiec 1988) ranges from 0 to $60 \mathrm{~m}$ in both analysed layers (Fig. 2).
The Cenozoic sediments are thickest in the south of the analysed area - of the order of 30-60 m while in the centre and north of the area they are mostly less than 20-m-thick. This is the case, for example, in the vicinity of the Daleszewice site, where the Cenozoic sediments range in thickness from 10 to $20 \mathrm{~m}$. More or less the same is true of the purely Quaternary deposits, with a slight difference in the north-west of the sheet.

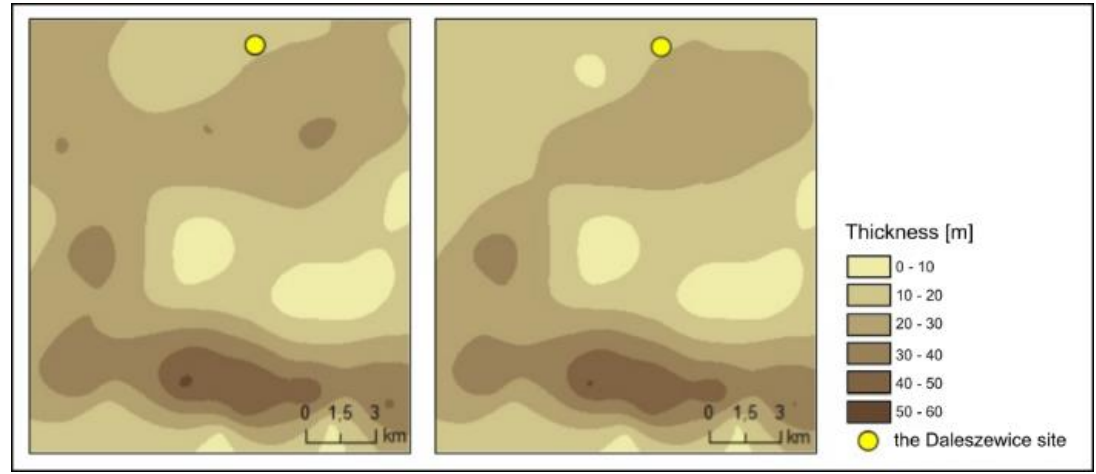

Fig. 2. Thickness of Cenozoic (left) and Quaternary (right) layers within the Żarnów DGMP sheet

The absolute terrain altitudes range from 180 to $277 \mathrm{~m}$ a.s.1., while the sub-Cenozoic surface ranges from 144 to $264 \mathrm{~m}$ a.s.l.

Analysis of the relief of the sub-Cenozoic surface (Fig. 3) shows that in the centre of the area there is a slight elevation rising about $80 \mathrm{~m}$ above the plateau and surrounded by a valley with a depth of up to $50 \mathrm{~m}$ relative to the plateau.
In large part, this valley coincides with the current course of the Czarna River valley. In the presentday landscape the hill is still visible, but it is lower and its slopes softer. The hill reaches about 60-mhigh. The valley has also been made more shallow. The difference in altitude between the valley bottom and the plateau reaches $20 \mathrm{~m}$.

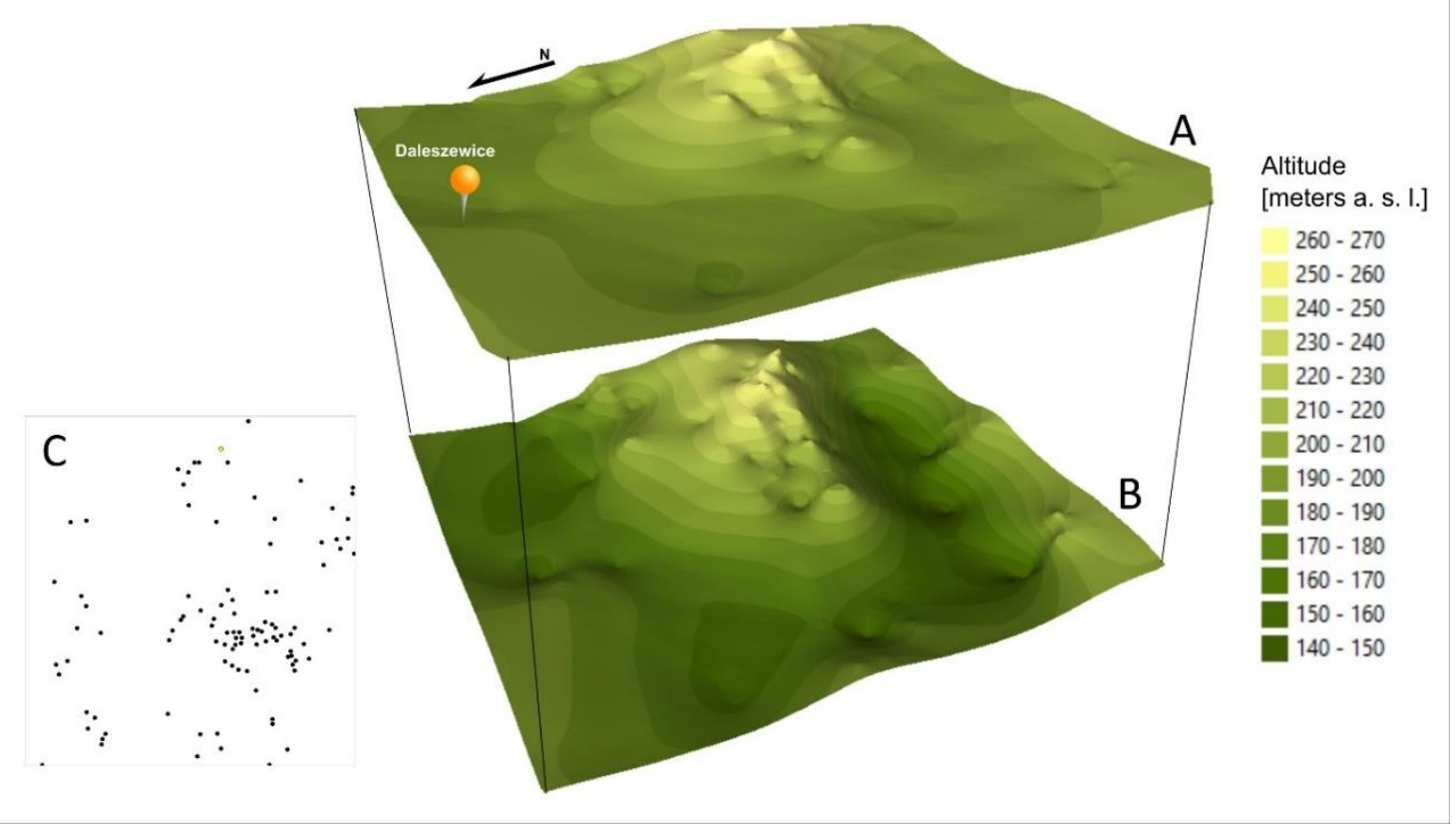

Fig. 3. Digital terrain model of the Żarnów DGMP map sheet: present-day surface topography (A) and sub-Cenozoic surface relief (B) and points map of geological drilling (C) 
The location of the undrained depression lies at an absolute height of $193 \mathrm{~m}$ a.s.1., while the height of the sub-Cenozoic surface is about $180 \mathrm{~m}$ a.s.l. The site is in a place where there is a slope in the sub-Cenozoic surface; this is the slope of the aforementioned valley.

\section{The Kykawe Doły site}

The thickness of Cenozoic deposits within the Ostrowy sheet (Kaziuk, Nowak 1999) is very uniform (Fig. 4). It ranges from 27 to $31 \mathrm{~m}$. The sediments are thickest in the north, centre and south of the sheet, ranging from 29 to 31 -m-thick. The sediment thickness is a little less in the west and east of the sheet, ranging from 27 to $29 \mathrm{~m}$. The thickness of Quaternary deposits is slightly less across the entire sheet, and ranges from 23 to
$28 \mathrm{~m}$. In the immediate vicinity of the Lykawe Doły site, the Cenozoic deposits are about 29-30$\mathrm{m}$-thick, while the Quaternary deposits are about 26-28-m-thick.

In the northern part of the map (Fig. 5), the terrain lowers noticeably on both the modern-day surface and the sub-Cenozoic surface maps. The south of the area is significantly higher. The difference between the lowest and highest point is over $70 \mathrm{~m}$ on the surface map, and over $80 \mathrm{~m}$ on the sub-Cenozoic surface map. Absolute heights in the portrayed area range from 212 to $293 \mathrm{~m}$ a.s.l. on the modern-day terrain map and from 175.6 to $272 \mathrm{~m}$ a.s.1. on the sub-Cenozoic surface map. The Łykawe Doły site lies in precisely the aforementioned depression, at an altitude of $212 \mathrm{~m}$ a.s.l. Here, the surface of the top of the Mesozoic is at $173 \mathrm{~m}$ a.s.l.

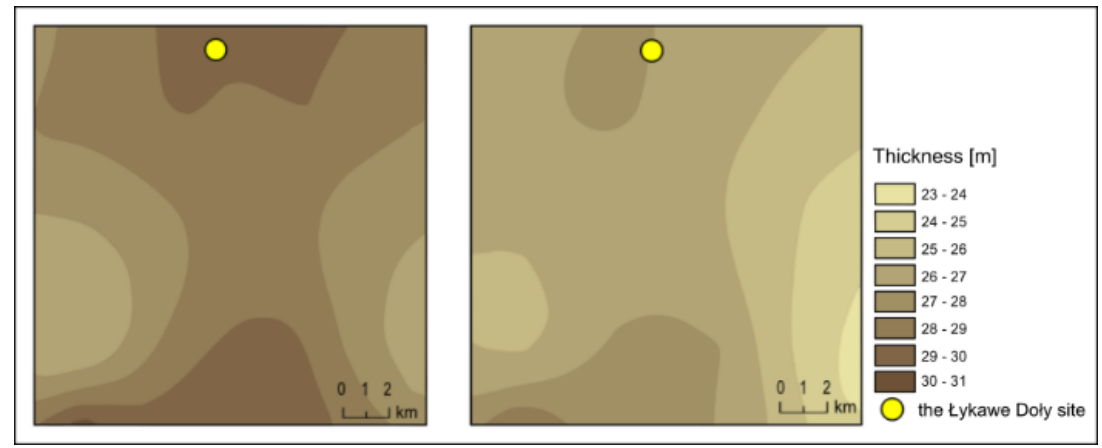

Fig. 4. Thickness of Cenozoic (left) and Quaternary (right) layers within the Ostrowy DGMP sheet

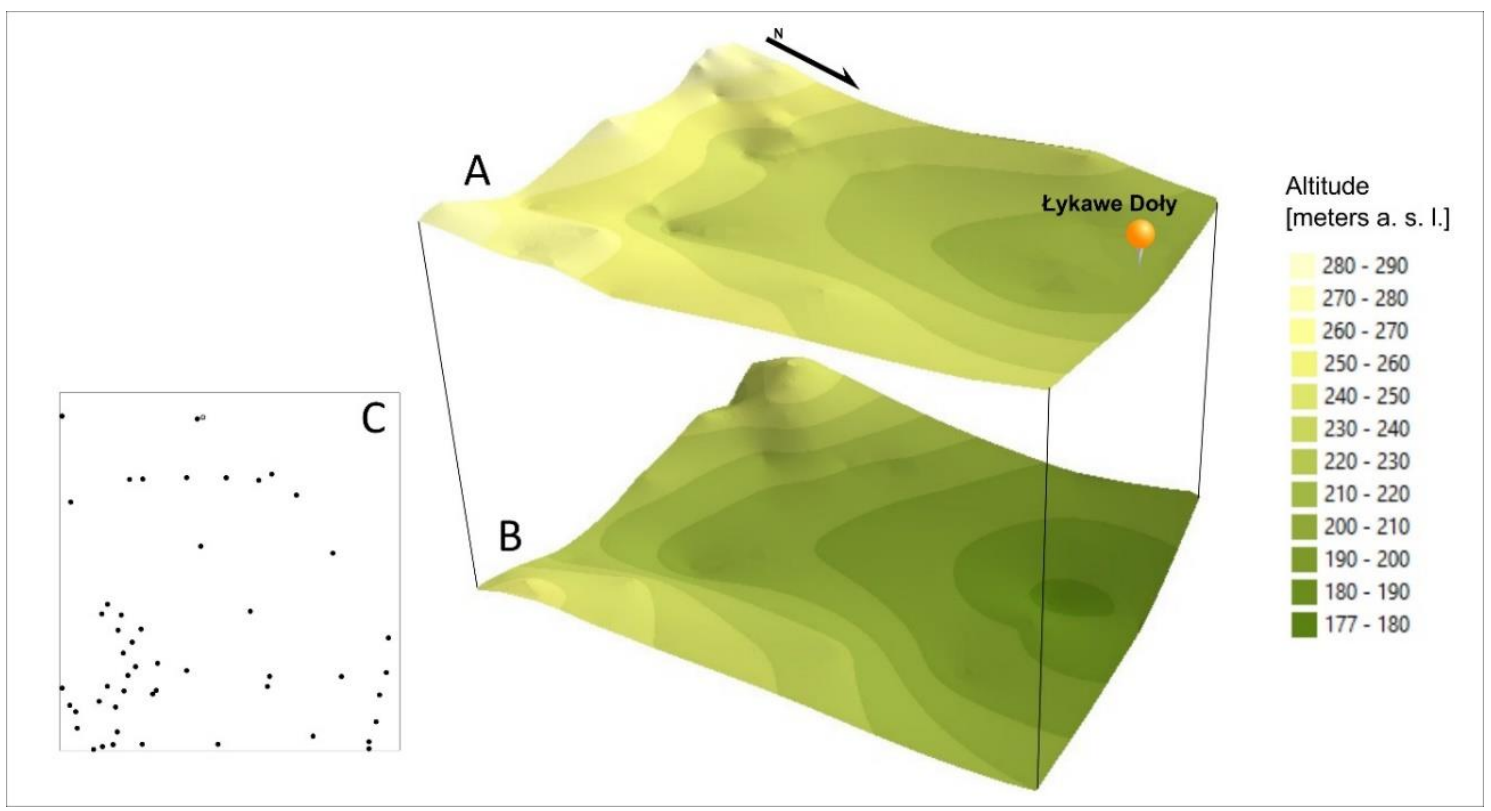

Fig. 5. Digital terrain model of the Ostrowy DGMP sheet: present-day surface topography (A) and sub-Cenozoic surface relief (B) and points map of geological drilling (C) 


\section{The Gaik-Winiary site}

The thickness of the Cenozoic deposits lying within the range of the Busko Zdrój sheet (Łyczewska 1972a) is far greater than that of the other two, ranging from 0 to $160 \mathrm{~m}$ (Fig. 6). The greatest thicknesses were recorded in the south and the east of the area, while in the central and north-western part they range from 0 to $40 \mathrm{~m}$. The Quaternary deposits are much less thick, reaching a maximum of $60 \mathrm{~m}$ in the south of the area, while everywhere else they are up to 20-m-thick. Near the Gaik-Winiary site, the thickness of deposits reaches 20 to $40 \mathrm{~m}$ for the Cenozoic, and 0 to $20 \mathrm{~m}$ for the Quaternary.
The Gaik-Winiary site has the most diverse contemporary and sub-Cenozoic surface topographies. The terrain surface has an altitude of 169 to $270 \mathrm{~m}$ a.s.l. (Fig. 7), while the absolute heights of the sub-Cenozoic surface range from 4 to $230 \mathrm{~m}$ a.s.l. The topography in the central part of the map is delineated by the Nida valley, while the northeast and south-west edges of the map are marked by the steep valley slopes. The height difference of these landforms is almost $90 \mathrm{~m}$. The surface relief of the Mesozoic sediments differs significantly. In the south-eastern part of the map there is a depression of more than 170-m-deep, and a relatively small hill of up to $230 \mathrm{~m}$ a.s.l. in the northern part of the map.

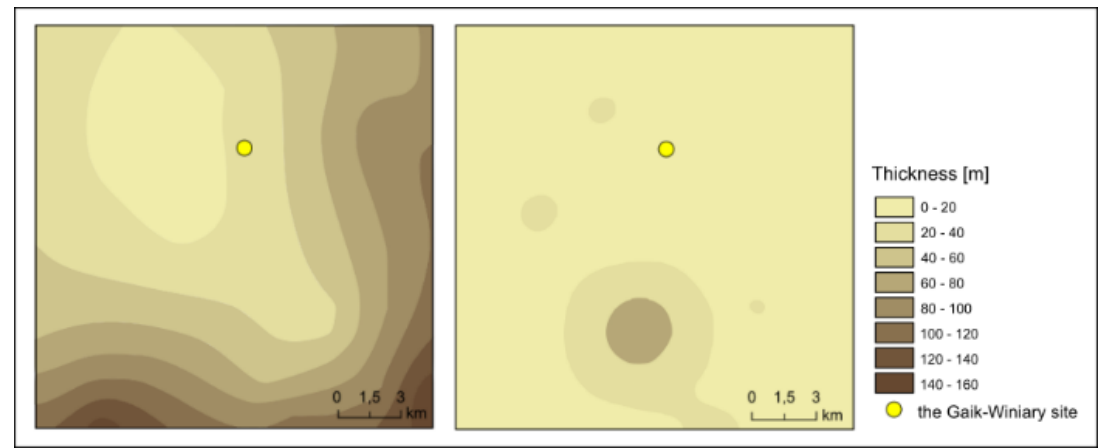

Fig. 6. Thickness of Cenozoic (left) and Quaternary (right) layers within the Busko Zdrój DGMP sheet

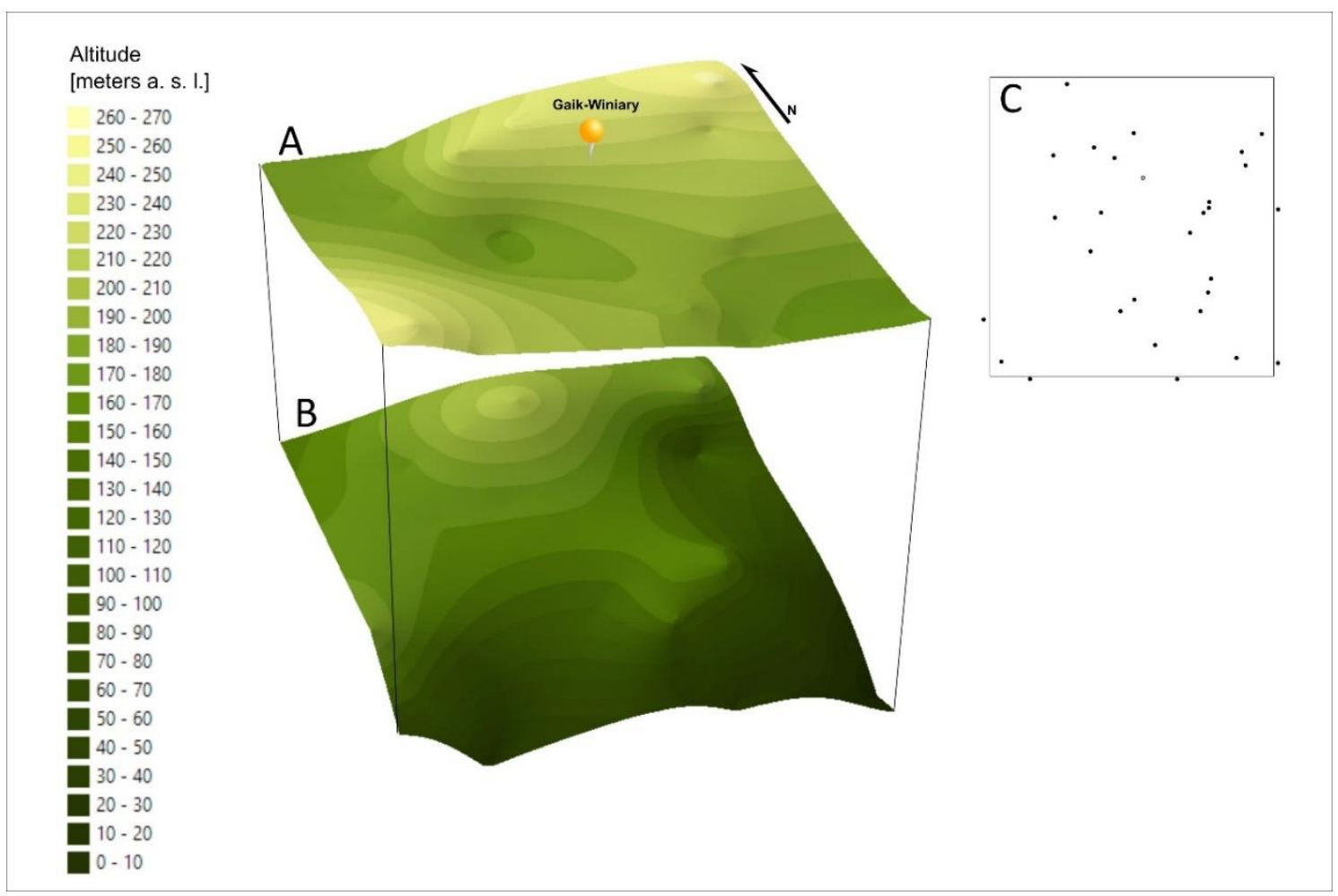

Fig. 7. Digital terrain model of the Busko Zdrój DGMP sheet: present-day surface topography (A) and sub-Cenozoic surface relief (B) and points map of geological drilling (C) 
The Gaik-Winiary site lies on a slope of the Nida valley where a slope of the aforementioned hill on the sub-Cenozoic surface is located. The absolute height of the surface is $225 \mathrm{~m}$ a.s.1., while the absolute height of the sub-Cenozoic surface is about $200 \mathrm{~m}$ a.s.1.

\section{Discussion}

The processes of karstification of Mesozoic sediments within the Małopolska Upland, in the form of the covered karst seen today on the terrain surface, began in the Holocene, but, according to Głazek (1989), in this region karst processes were active much earlier. It can therefore be assumed that the covering-over of the karst rocks with younger (Neogene and Quaternary) deposits resistant to this type of erosion only slowed or temporarily halted the previously occurring processes. They were reactivated as covered karst processes and the formation of concave forms on the surface in conducive conditions associated with groundwater circulation (Liszkowski 1967). The main factor here is the thickness of the layer of karstification-resistant sediments covering the actively karstifying rocks, in combination with the type of rocks in the ground (carbonate rocks, such as limestones, marls or gypsums, covered with poorly permeable sediments, e.g. glacial till) (Veress 2016). When these conditions are met, the overlying sediments, as they fill the spaces resulting from rock karstification, simultaneously create non-drained depressions on the land surface, which in turn are filled with biogenic sediments (Różycki 1946). The filling of the depressions follows a specific pattern in which a depression is initially sealed by mineral deposits and the bowl is then filled with water and gradually overgrown. This process was described in detail by Różycki (1946). After additional analyses the pattern was verified and simplified (Brzozowicz 2016b).

The course of the entire process of formation and development of undrained covered karst depressions and its undisturbed continuity are extremely important for palaeoecological research on the Holocene in the Małopolska Upland. The nature of the bedrock is therefore particularly important in determining whether a given location might feature covered karst, and the course this process may take. Much valuable information of use in understanding this problem is contained in Veress's (2016) publication on sub-surface karst processes, which describes what rocks and arrangement of rocks are conducive to the deve- lopment of underground karst processes. As the author explains, limestone karsts may cover more extensive areas than gypsum karst, but the density and size of the latter karst forms may be greater under similar hydrogeological conditions. Of great importance in how intensely karst (incl. covered karst) develops are the crevices and fractures in the karst rocks that facilitate groundwater circulation and the leaching of material (Veress 2016). This factor was also pointed out by Różycki (1946) in seeking connections between the arrangement of karst forms and the possibility of fissures occurring in the sub-Quaternary layer of Jurassic limestones.

Daleszewice and Łykawe Doły are typical covered karst forms for the Małopolska Upland. They were chosen for detailed study for the considerable thickness of the biogenic deposits that fill them. However, these are not the only forms of this kind in these areas. In the case of Daleszewice, more than 30 karst depressions (Różycki 1946) have been recorded at various stages of development in the immediate vicinity (Brzozowicz 2016b). Not far from the Łykawe Doły site there are also a considerable number of covered karst forms that have been described by Nowak (1993) and Kobojek (2004). Most of these forms have depths of several tens of centimetres (Kobojek 2004) to as much as four metres (Brzozowicz 2016a). Urban (2015) writes about the multiplicity of concave forms associated with covered karst in Niecka Nidziańska. Most of these forms are dry karst funnels, though, as indicated by Okupny and Jucha (2020), some have filled with biogenic sediments, and peatlands have formed within them. This is the case at, for example, the Gaik-Winiary site.

Niecka Solecka differs geologically from the other sites. On the terrain surface, and just below the Quaternary surface in places, Neogene gypsums occur. Urban (2015) describes this area as unique within the country because of the present activity of karst processes in these rocks. The formation of covered karst landforms is also associated with gypsum rocks. However, as the collected data show, the Mesozoic rocks in this place lie under a thin layer of younger sediments, as at the other two sites. The overlying layer sediments reaches about $40 \mathrm{~m}$ thick. This arrangement of rocks can cause covered karst processes to develop in gypsum rocks, but also in deeper-lying Mesozoic rocks. Similar landforms of karst origin have also been described in the south of the Małopolska Upland by, for example, Walczowski (1964), Szczepanek (1971) and Zieliński (2013). Most of these landforms are filled with water, forming karst lakes. A significant difference is the geolo- 
gical structure of their substrate. As with Niecka Solecka, the karst processes in Niecka Połaniecka are associated with a gypsum series, while the difference is the sandy substrate. This changes how the gypsum rocks are leached and can also affect the development of covered karst processes.

Covered karst forms also occur outside the Małopolska Upland, e.g. in Polesie. Łojek (2019) describes concave forms in Pagóry Chełmskie (the Chełm Hills). The forms there are much more clearly evident in the landscape than those in the Małopolska Upland. This may be caused by the non-karsting deposits that cover the carbonate rocks being much thinner: the layer is about 2-3$\mathrm{m}$-thick. In the case of Daleszewice and Łykawe Doły, the thickness of the Quaternary sediments is about $20-30 \mathrm{~m}$, so the terrain surface exhibits far more serious karst events.

While analysing the collected material, it was decided to attempt to reconstruct the contemporary terrain surface and the surface of Mesozoic rocks using three-dimensional digital terrain models. The publication of Andrews et al. (2002) describes a method for compiling geological data that allows a reliable image of the landform to be obtained as a three-dimensional model. They described a scheme for preparing such a terrain model and drew attention, among other things, to how compact the data network should be, how to process the collected data, and how to select parameters to obtain correct models. The performed models showed in which terrain conditions all three drainage depressions were created. As it turned out, the Daleszewice site and the Gaik-Winiary site are located on the slopes of a valley formed in Mesozoic rocks, while the Łykawe Doły site is located at the bottom of the Mesozoic basin. However, it should be borne in mind that the density of the geological drilling network applied in detailed geological mapping varies, and is not always sufficient to map the shape of the Mesozoic surface in detail. Similar visualizations on the Wielun Upland and Częstochowa Upland were made by Szubert (2007), which also involved data from geological boreholes previously made for the needs of geological maps that were processed using GIS technology. Szubert (2007) also drew attention to the uneven distribution of geological boreholes, which made it difficult to fully visualize the sub-Quaternary surface. Despite the varied detail of the maps, they are a good tool for visualising the landform of rock layers that we cannot see with the naked eye.

As pointed out in the Introduction, the main research problem that analyses of contemporary karst depressions have been undertaken to address are the biogenic deposits that fill them. However, to properly reconstruct the process of the depressions' formation and the course of their infilling, it is necessary to recognise their carbonate bedrock and the possibility of karst processes having been active in the Holocene. Palaeobotanical analyses of the biogenic material deposited in the covered karst depressions are made difficult by the state of preservation of the remains and the habitat characteristics of such depressions. However, the low total number of wetlands and lakes in the Małopolska Upland zone means that the results of the conducted works may expand our palaeoecological understanding of the Holocene in this part of the country.

\section{Conclusions}

For covered karst to occur, certain geological conditions must be met that relate to, for example, a thin layer of non-karsting sediments covering the rocks undergoing karstification, the particular kind of these rocks, and the relief of the Mesozoic surface. The sources analysed show that two of the three sites meet these conditions. The bedrock around the Daleszewice and Łykawe Doły sites contains Jurassic rocks, mainly limestones and marls, and the overlying sediments are no more than 20-30-m-thick. At the third site - that in Niecka Nidziańska - the situation is slightly different, as the literature reveals that karst processes there are developing in Neogene gypsums. However, the gathered data indicate that in this case the Mesozoic rocks also lie at a shallow depth of about $40 \mathrm{~m}$, while the Quaternary layer reaches no more than $20 \mathrm{~m}$. This arrangement of rocks in the substratum leads us to suppose that, here, karst may be developing both in the gypsum and in the Mesozoic rocks. To determine which rocks predominated in the formation of the studied undrained depression, further geological surveys should be performed.

The analysis of three-dimensional maps revealed the relief of the Mesozoic surface. All three maps showed that where depressions associated with covered karst occur in the modern-day topography, the Mesozoic surface, too, exhibits a depression. In the case of the Daleszewice and GaikWiniary sites, these are valley slopes, while at the Łykawe Doły site it is the bottom of the trough. This state of affairs indicates that the development of covered karst landforms may be facilitated by surficial water flow between the Mesozoic surface and the layer of Cenozoic sediments. 


\section{References}

Andrews B.D., Gares P.A., Colby J.D. 2002. Techniques for GIS modeling of coastal dunes. Geomorphology 48: 289-308.

Brzozowicz D. 2016a. Geneza i rozwój małych zagłębień bezodpływowych na północ od Paradyża. Maszynopis pracy magisterskiej. WNG UŁ.

Brzozowicz D. 2016b. Stadia rozwoju zapadlisk krasowych w Daleszewicach koło Paradyża. Prace Studenckiego Koła Naukowego Geografów Uniwersytetu Pedagogicznego w Krakowie 5: 12-16.

Brzozowicz D. 2018. Analiza litologii osadów podłoża zagłębień bezodpływowych krasu reprodukowanego w północnej części Wzgórz Opoczyńskich. In: M. Bogusz, M. Wojcieszak, P. Rachwał (eds.) Poszerzamy horyzonty. t. IX. Wyd. Mateusz Weiland Network Solutions Słupsk: 256-262.

Brzozowicz D., Forysiak J. 2016. Warunki funkcjonowania i rozwój torfowiska w zagłębieniu krasowym w okolicach Paradyża. Acta Geographica Lodziensia 105: 69-79.

Gałka M. 2006. Warunki wodne. Objaśnienia do mapy geośrodowiskowej Polski, arkusz Busko Zdrój (917). Państwowy Instytut Geologiczny, Warszawa: 16-20.

Głazek J. 1989. Paleokarst of Poland. In: P. Bosák, D. Ford, J. Głazek, I. Horaček (eds.) Paleokarst: A systematic and regional review. Elsevier, Amsterdam: 77-105.

Janiec J. 1988. Szczegółowa mapa geologiczna Polski 1:50 000, arkusz Żarnów. Państwowy Instytut Geologiczny, Warszawa.

Janiec J. 1993. Objaśnienia do Szczegółowej mapy geologicznej Polski 1:50 000, arkusz Żarnów. Państwowy Instytut Geologiczny, Warszawa.

Kaziuk H., Nowak B. 1999. Szczegółowa mapa geologiczna Polski 1:50 000, arkusz Ostrowy. Państwowy Instytut Geologiczny, Warszawa.

Kaziuk H., Nowak B. 2014. Objaśnienia do Szczegółowej mapy geologicznej Polski 1:50 000, arkusz Ostrowy. Państwowy Instytut Geologiczny, Warszawa.

Kobojek S. 2004. Osady zagłębień bezodpływowych na Wyżynie Wieluńskiej. In: A. Kostrzewski (ed.) Geneza, litologia i stratygrafia utworów czwartorzędowych. Wyd. Nauk. UAM, Poznań: 181-195.

Kobojek S., Nalej M. 2008. Formy krasu reprodukowanego w południowej części Wyżyny Wieluńskiej. Landform Analysis 9: 247-250.

Kondracki J. 1998. Geografia regionalna Polski. PWN, Warszawa.

Liszka P., Guzik M., Zembal M. 2000. Mapa hydrogeologiczna Polski, arkusz Ostrowy (809). Państwowy Instytut Geologiczna, Warszawa.
Liszkowski J. 1967. Podstawy klasyfikacji zjawisk i procesów krasowych dla potrzeb praktyki inżyniersko-geologicznej i hydrogeologicznej. Przegląd Geologiczny 5: 225-230.

Łojek J. 2019. Warunki rozwoju krasowych form wertebowych w wyżynnej części międzyrzecza Wisły i Bugu w świetle analiz przestrzennych i rekonstrukcji paleośrodowiskowych. Praca doktorska. Zakład Geomorfologii i Paleogeografii UMCS, Lublin.

Łyczewska J. 1972a. Szczegółowa mapa geologiczna Polski 1:50 000, arkusz Busko-Zdrój. Wyd. Geol., Warszawa.

Łyczewska J. 1972b. Objaśnienia do Szczegółowej mapy geologicznej Polski 1:50 000, arkusz Busko-Zdrój. Wyd. Geol., Warszawa.

Mapa hydrograficzna Polski arkusz M-34-27-C. Główny Urząd Geodezji i Kartografii, Warszawa.

Marks L., Dzierżek J., Janiszewski R., Kaczorowski J., Lindner L., Majecka A., Makos M., Szymanek M., Tołoczko-Pasek A., Woronko B. 2016. Quaternary stratigraphy and palaeogeography of Poland. Acta Geologica Polonica 66(3): 403-427.

Mizerski W. 2020. Geologia Polski. Wyd. Nauk. PWN, Warszawa.

Nowak W.A. 1971. Kras reprodukowany wschodniej części Wyżyny Częstochowskiej. Folia Geographica, Series Geographica Physica 5: 6585.

Nowak W.A. 1993. Skrasowienie podziemne wapieni i jego odzwierciedlenie w rzeźbie Wyżyny Krakowsko-Wieluńskiej w rejonie Częstochowy. Studia Ośrodka Dokumentacji Fizjograficznej 21: 9-157.

Okupny D., Jucha W. 2020. Znaczenie warunków geologicznych i geomorfologicznych dla rozwoju i współczesnego stanu torfowisk Niecki Nidziańskiej. Przegląd Geologiczny 68(2): 135144.

Rdzany Z. 2009. Rekonstrukcja przebiegu zlodowacenia warty w regionie łódzkim. Wyd. UŁ, Łódź.

Różycki S. 1946. Przyczynki do znajomości krasu Polski. I. Kras opoczyński. Przegląd Geograficzny 20: 107-127.

Rutkowski J. 1986. Budowa geologiczna Niecki Nidziańskiej. Studia Ośrodka Dokumentacji Fizjograficznej 14: 35-61.

Szczepanek K. 1971. Kras staszowski w świetle badań paleobotanicznych. Acta Paleobotanica 12(2): 63-140.

Szubert M. 2007. Geoinformatyka w geomorfologii na przykładzie badań geomorfologicznych na Wyżynie Wieluńskiej i Częstochowskiej. Archiwum Fotogrametrii, Kartografii i Teledetekcji 17b: 759-768.

Urban J. 2015. Warunki rozwoju i wiek krasu w gipsach Niecki Soleckiej. Biuletyn Państwowego Instytutu Geologicznego 462: 125-152. 
Veress M. 2016. Covered karsts. Springer, Dordrecht. Walczowski A. 1964. Zjawiska krasowe południowowschodniego obrzeżenia Gór Świętokrzyskich. Annales Universitatis Mariae Curie-Sklodowska, sec. B 19(2): 29-62.
Zieliński A. 2013. Rozwój jezior krasowych w Niecce Połanieckiej. Wyd. Uniw. Jana Kochanowskiego, Kielce. 